\title{
PERBANDINGAN PROFIL HUJAN VERTIKAL RADAR CUACA DENGAN MICRO RAIN RADAR SELAMA KEJADIAN HUJAN SEDANG (Studi Kasus : Intensive Observation Period 2016)
}

\author{
A Comparison of Vertical Rain Profile between Weather Radar and \\ Micro Rain Radar during a Moderate Rain Event \\ (Case Study : 2016 Intensive Observation Period)
}

\author{
Sunu Tikno ${ }^{1)}$, Rino Bahtiar Yahya ${ }^{2)}$, Sara Aisyah Syafira ${ }^{3)^{*}}$ \\ ${ }^{1,2,3)}$ Balai Besar Teknologi Modifikasi Cuaca - Badan Pengkajian dan Penerapan Teknologi, Gedung Ir. \\ Mohammad Soebagio, GEOSTECH (820), Kawasan PUSPIPTEK, Serpong, Tangerang Selatan \\ *E-mail : sara.aisyah@bppt.go.id
}

\begin{abstract}
Intisari
Micro Rain Radar (MRR) merupakan suatu instrumen pengamatan hujan, yang beroperasi secara vertikal. Sementara itu, radar cuaca WR-2100 biasa digunakan untuk membuat suatu profil yang berupa cakupan area. Akan tetapi, dengan pengolahan lebih lanjut, data suatu radar cuaca seperti radar cuaca WR-2100 tersebut juga dapat digunakan untuk menampilkan profil vertikal salah satu parameternya di suatu lokasi tertentu. Penelitian kali ini membandingkan profil vertikal hujan di Dramaga, Bogor berdasarkan nilai rain rate nya yang diperoleh dari MRR yang beroperasi secara langsung di lokasi tersebut dengan profil serupa yang diperoleh dari radar cuaca WR-2100 yang beroperasi di lokasi berbeda, yaitu di Serpong, Tangerang Selatan. Hasil penelitian menunjukan bahwa kedua instrumen tersebut mendeteksi adanya nilai rain rate pada waktu-waktu yang bersamaan, namun dengan nilai yang lebih tinggi oleh radar cuaca WR-2100 untuk lapisan-lapisan yang lebih tinggi, yang terutama diduga karena atenuasi yang lebih besar dan signifikan yang terjadi pada proses pengukuran oleh MRR untuk lapisan-lapisan yang lebih tinggi pada saat kejadian-kejadian hujan sedang.
\end{abstract}

Kata Kunci : MRR, Radar Cuaca, Rain Rate, Profil Vertikal.

\begin{abstract}
Micro Rain Radar (MRR) is an instrument to observe precipitation, especially rainfall, that operate vertically. Besides, a weather radar, WR-2100, is an instrument making profile in an area scope. By doing further processing, data of weather radar WR-2100 can be used to show vertical profile of a certain parameter in a certain location. This study compared vertical profile of rain rate at Dramaga, Bogor, based on data of MRR operated in same location with that based on data of weather radar WR-2100 operated in different location, which is Serpong, Tangerang Selatan. Results of the study showed that both instruments detected rain rate values on same times, while the values are higher at higher altitudes for weather radar WR-2100 than for MRR due to higher and more significant attenuation happened in MRR operation at higher altitude in moderate rainfall events.
\end{abstract}

Keywords : MRR, Weather Radar, Rain Rate, Vertical Profile.

\section{PENDAHULUAN}

Terdapat beberapa jenis radar cuaca yang sangat bervariasi bentuk dan ukurannya, mulai dari Radar X-band, K-band, W-band, dan Sband. Kebanyakan radar cuaca modern memiliki kapabilitas Doppler. Beberapa memiliki kemampuan untuk mengubah polaritas. Beberapa memiliki kombinasi kedua kemampuan tersebut (Rinehart, 2010). Radar cuaca pada prinsipnya mampu memberikan perkiraan kuantitatif bidang cuaca curah hujan dengan suatu resolusi temporal dan spasial yang tinggi (Berne \& Uijlenhoet, 2006). Dijelaskan oleh
Rinehart (2010) kekuatan sinyal yang kembali ke radar tergantung pada faktor reflektivitas radar $z$ suatu pantulan (echo) cuaca. Sebaliknya, reflektivitas tergantung pada jumlah dan diameter butir hujan yang tersedia dalam volume sampel radar. Salah satu contoh dari radar cuaca adalah radar tipe WR-2100, yang merupakan radar dual polarimetric jenis $\mathrm{X}$-band dan beroperasi pada frekuensi $9.4 \mathrm{GHz}$.

Radar tipe WR-2100 ini beserta radar cuaca lainnya, biasa digunakan untuk menyediakan profil berupa cakupan area. Terdapat dua mode operasi utama yang biasa terdapat pada radar cuaca, yaitu PPI (Plan 
Position Indicator) dan $\mathrm{RHI}$ (Range Height Indicator). Pada mode PPI, radar beroperasi dengan sudut elevasi yang konstan namun bervariasi sudut azimutnya. Radar tersebut bisa berputar hingga $360^{\circ}$ atau kurang dari itu sesuai yang dikehendaki. Pada mode RHI, sebaliknya, radar beroperasi pada sudut azimut yang tetap dengan sudut elevasi yang berubah-ubah.

Pada pengoperasian radar dengan mode PPI, pengamatan dapat dilakukan untuk lebih dari satu sudut elevasi yang diinginkan, sehingga putaran kedua radar berada pada sudut elevasi yang berbeda dengan putaran pertama dan begitu seterusnya hingga radar kembali ke sudut elevasi awal, sesuai dengan banyaknya sudut elevasi yang diamati dalam pengaturan. Mode pengoperasian seperti ini juga sering dikenal sebagai volume scan. Hasil pengamatan dari beberapa sudut elevasi tersebut kemudian dapat dikompositkan, menghasilkan sekumpulan data CAPPI (Constant Altituted Plan Position Indicator) yang menunjukkan profil radar di suatu cakupan area pada ketinggian-ketinggian tertentu yang konstan.

Salah satu parameter penting keluaran radar cuaca adalah rain rate yang menunjukkan banyaknya curah hujan per satuan waktu atau dengan kata lain intensitas suatu kejadian hujan, dengan satuan $\mathrm{mm} / \mathrm{h}$ (milimetre/hour). Dengan melakukan pengolahan terhadap sekumpulan data CAPPI, profil vertikal dari kondisi hujan di suatu titik lokasi tertentu, yang diwakili dengan nilai rain rate, dapat diperoleh.

Dalam perkembangan teknologi dewasa ini terkait dengan pengukuran parameter cuaca, telah dikembangkan suatu instrumen baru sejenis radar yang berfungsi mengamati presipitasi, khususnya hujan, yang disebut Micro Rain Radar (MRR). Tidak seperti radar WR-2100 atau radar cuaca lainnya, MRR ini memang dioperasikan sebagai pembuat profil secara vertikal (Peter et al., 2002). Micro Rain Radar (MRR) merupakan radar Doppler yang beroperasi secara tegak lurus (vertikal) dan memanfaatkan prinsip kerja gelombang kontinyu dengan frekuensi termodulasi (Frequency Modulated Continuous Wave, FM-CW) pada 24.1 $\mathrm{GHz}$. Ketinggian pengukuran karakteristik hujan oleh MRR dapat mencapai hingga $9 \mathrm{~km}$, dengan resolusi waktu 10 detik dan resolusi ketinggian 300 m (Chakravarty et al., 2014).

Penelitian ini bertujuan membandingkan profil hujan vertikal di suatu lokasi (Dramaga, Bogor) yang diperoleh dari data micro rain radar (MRR) yang beroperasi secara langsung di lokasi tersebut dengan data profil hujan vertikal yang diperoleh dari data radar cuaca WR-2100 yang beroperasi di lokasi berbeda (Serpong, Tangerang Selatan) pada kejadian-kejadian hujan sedang selama kegiatan "intensive periode observation (IOP) during java rainy season for extreme weather study" 18 Januari - 16 Februari
2016 yang diselenggarakan oleh BPPT dan BMKG.

\section{METODE}

\subsection{Waktu dan Lokasi Penelitian}

Penelitian dilakukan di dua lokasi posko kegiatan intensive periode observation (IOP) during java rainy season for extreme weather study 18 Januari -16 Februari 2016 oleh BPPT dan BMKG, yaitu posko Dramaga yang bertempat di Stasiun Klimatologi Klas I Darmaga, Bogor dan posko Serpong yang berada di kawasan GEOSTECH, Puspiptek, Serpong, Tangerang Selatan. Micro rain radar (MRR) dioperasikan di posko Dramaga, sedangkan Radar Cuaca Furuno WR-2100 dioperasikan di posko Serpong.

Sebagai data pendukung kejadian hujan, dioperasikan pula penakar hujan (rain gauge) di posko Dramaga.

\subsection{Pengoperasian Micro Rain Radar (MRR)}

Pada penelitian kali ini, MRR dioperasikan setiap hari pukul 07.00-19.00 WIB dengan ketinggian lapisan pengamatan/pengukuran adalah kelipatan $250 \mathrm{~m}$ mulai dari ketinggian 250 $\mathrm{m}$ hingga $7750 \mathrm{~m}$. Dengan begitu terdapat masing-masing 31 lapisan yang diamati dalam 1 kali pengukuran.

\subsection{Pengoperasian Radar Cuaca Furuno WR-2100}

Radar cuaca Furuno WR-2100 dioperasikan dengan mode PPI (Plan Position Indicator) yang berputar pada sudut azimut sejauh $0^{\circ}-360^{\circ}$ dalam satu kali putaran. Dalam penelitian ini, terdapat 12 sudut elevasi yang digunakan dalam pengoperasian radar tersebut, yaitu; $0.5^{\circ}, 1.5^{\circ}, 2.4^{\circ}, 3.4^{\circ}, 4.3^{\circ}, 5.3^{\circ}, 6.2^{\circ}, 7.5^{\circ}$, $8.7^{\circ}, 10^{\circ}, 12^{\circ}$, dan $15^{\circ}$. Radar akan berputar pada sudut azimut sejauh $0^{\circ}-360^{\circ}$ di setiap sudut elevasi secara bergantian dari sudut elevasi pertama hingga sudut elevasi terakhir, lalu kembali ke sudut elevasi pertama, dan begitu seterusnya secara berulang. Radar ini beroperasi setiap hari dan sepanjang hari.

\subsection{Pengolahan Data MRR dan Data Radar Cuaca WR-2100}

Pengolahan data MRR dilakukan menggunakan program METEK Graphic Software untuk menampilkan nilai rain rate $(\mathrm{RR})$ nya dalam bentuk profil warna berdasarkan ketinggian dan waktu.

Hal serupa juga dilakukan terhadap data radar cuaca WR-2100 menggunakan GrADS (Grid Analysis and Display System) dengan menampilkan datanya hanya pada satu titik lokasi tertentu yang merupakan lokasi yang sama 
dengan lokasi keberadaan dan pengamatan MRR, yaitu Stasiun Klimatologi Klas I Darmaga, Bogor, yang berada di $106^{\circ} 44^{\prime} 36.9^{\prime \prime} \mathrm{BT}, 06^{\circ} 33^{\prime}$ 12.6" LS. Dalam GrADS, pengaturan lokasi ditampilkannya data radar tersebut dituliskan sebagai berikut:

'set lon 106.7436'

'set lat -6.5535'

Dikarenakan adanya interpolasi atau keterbatasan resolusi tertentu, nilai bujur dan lintang yang ditampilkan berdasarkan pengaturan di atas adalah $106.745^{\circ}$ dan $6.55253^{\circ}$.

Sebelum diolah menggunakan GrADS, data radar keluaran alat yang masih berupa data PPI (Plan Position Indicator) lebih dahulu dikompositkan untuk dapat menghasilkan sekumpulan data CAPPI (Constant Altituted Plan Position Indicator). Dari sekumpulan data CAPPI ini, barulah dapat dibuat profil vertikal salah satu parameternya menggunakan GrADS.

Format awal data radar cuaca Furuno WR2100 berekstensi .scn. Dengan menggunakan perangkat lunak "furuno2draft", format .scn tersebut dikonversi ke format data radar yang umum, dengan ekstensi .rtf. Selain itu, perangkat lunak "furuno2draft" ini juga akan memecah 1 file .scn menjadi 8 file, yang masing-masing untuk 8 parameter berbeda, yaitu dBz, V, w, ZDR, PhiDP, KDP, RhoHV, dan rain. Parameter yang digunakan dalam penelitian ini adalah parameter rain saja (rain rate, $\mathrm{mm} / \mathrm{hour}$ ).

Data yang telah diolah menggunakan perangkat "furuno2draft" masih dalam bentuk PPI. Sesuai namanya, keluaran dari perangkat "furuno2draft" ini selanjutnya menjadi masukan pada perangkat "draft" untuk dikompositkan dan diolah menjadi sekumpulan data CAPPI.

\section{HASIL DAN PEMBAHASAN}

Berdasarkan hasil pengukuran curah hujan penakar harian selama kegiatan IOP, diketahui bahwa itensitas curah hujan tertinggi masih berada pada kategori hujan sedang menurut BMKG (20-50 mm/hari), yaitu $48 \mathrm{~mm}$. Oleh karena itu, penelitian kali ini menggunakan data semua hari dengan kejadian hujan sedang selama periode penelitian (IOP) tersebut. Terdapat 5 hari dengan curah hujan sedang. Ke 5 hari tersebut yang akan dibandingkan profil hujannya secara vertikal dari pukul 07.00 hingga pukul 19.00 WIB berdasarkan data MRR dan berdasarkan data radar cuaca WR-2100. Ke 5 hari tersebut yaitu; 28 Januari (48 mm), 31 Januari $(30.7 \mathrm{~mm}), 2$ Februari $(33.5 \mathrm{~mm}), 8$ Februari (47.7 mm), dan 14 Februari 2016 (39 $\mathrm{mm})$.

Gambar 1 memperlihatkan profil rain rate di lapisan $250 \mathrm{~m}$ hingga $7500 \mathrm{~m}$ pada pukul 07.00-19.00 WIB untuk kelima tanggal ((a)-(e)), baik berdasarkan hasil olahan data MRR (kiri, i) maupun data radar cuaca WR-2100 (kanan, ii).
Dalam pengolahan menggunakan GrADS, profil radar cuaca WR-2100 juga ditampilkan mulai dari ketinggian $250 \mathrm{~m}$.

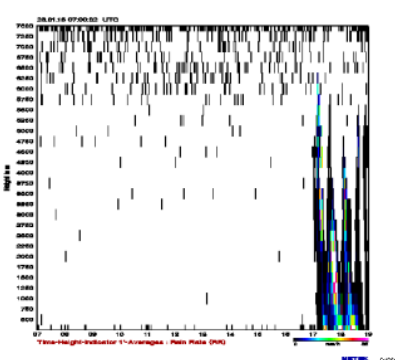

(a) $\mathrm{i}$

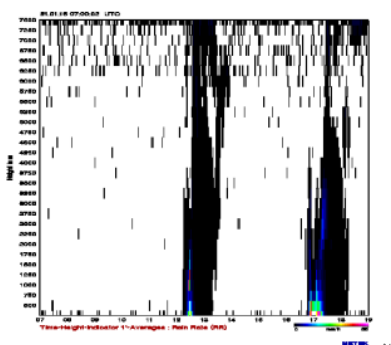

(b) $\mathrm{i}$

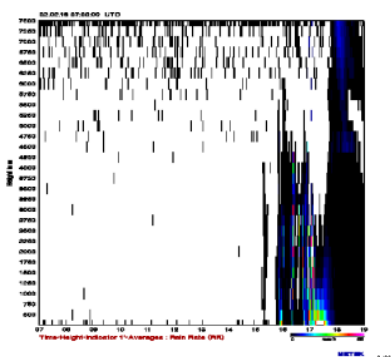

(c) $\mathrm{i}$

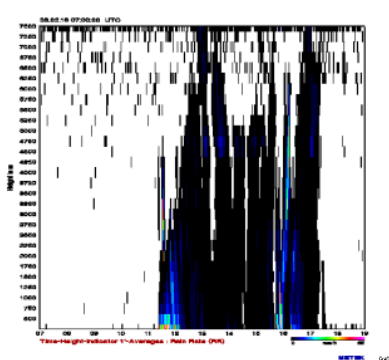

(d) $\mathrm{i}$

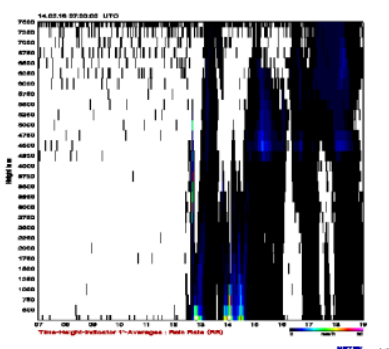

(e) $\mathrm{i}$

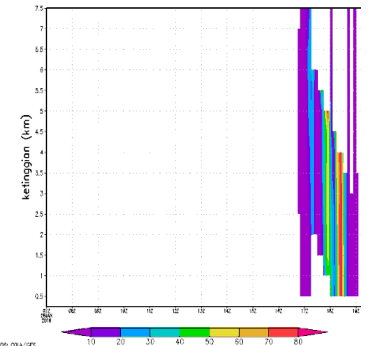

(a) ii

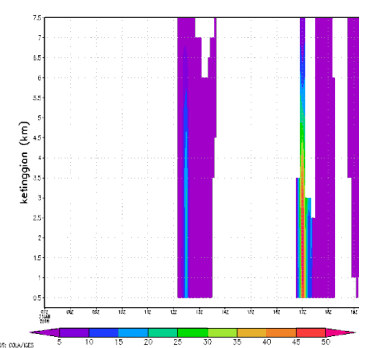

(b) ii

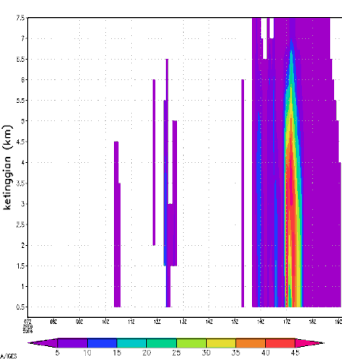

(c) $\mathrm{ii}$

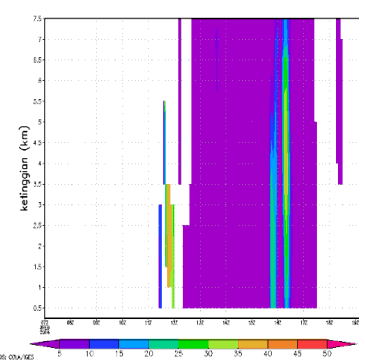

(d) ii

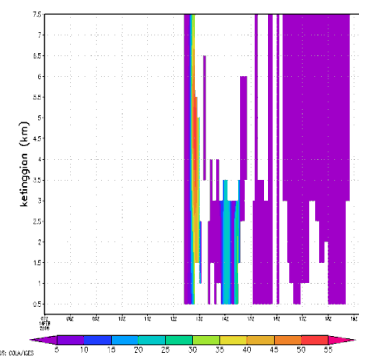

(e) ii
Gambar 1. Profil Rain Rate pukul 07.00-19.00 WIB tanggal 28 Januari (a), 31 Januari (b), 2

Februari (c), 8 Februari (d), dan 14 Februari 2016 (e) berdasarkan MRR (i) dan berdasarkan radar WR-2100 (ii). 
Data CAPPI radar cuaca WR-2100 hasil olahan menggunakan perangkat "draft" didefinisikan sebagai data dengan ketinggian paling rendah $500 \mathrm{~m}$ dan resolusi juga $500 \mathrm{~m}$, sehingga nilai yang terlihat pada profil rain rate oleh radar cuaca WR-2100 selalu kosong untuk ketinggian kurang dari $500 \mathrm{~m}$.

Jarak lokasi keberadaan radar cuaca WR2100 (Kawasan GEOSTECH, Puspiptek, Serpong) dengan lokasi yang dipantau yang juga merupakan lokasi keberadaan MRR (Stasiun Klimatologi Klas I, Darmaga, Bogor) adalah sekitar 23,46 km. Berdasarkan Gambar 1, terlihat bahwa dengan sudut elevasi tertinggi $15^{\circ}$, nilai rain rate di lapisan $7500 \mathrm{~m}$ masih dapat terdeteksi oleh radar WR-2100 yang berada pada jarak sekitar 23,46 km dari lokasi yang dipantau. Gambar 2 berikut ini menunjukkan grafik ketinggian jelajah radar dari permukaan bumi berdasarkan fungsi jarak dari pusat radar untuk sudut-sudut elevasi tertentu, dengan mempertimbangkan bentuk bumi yang bulat.

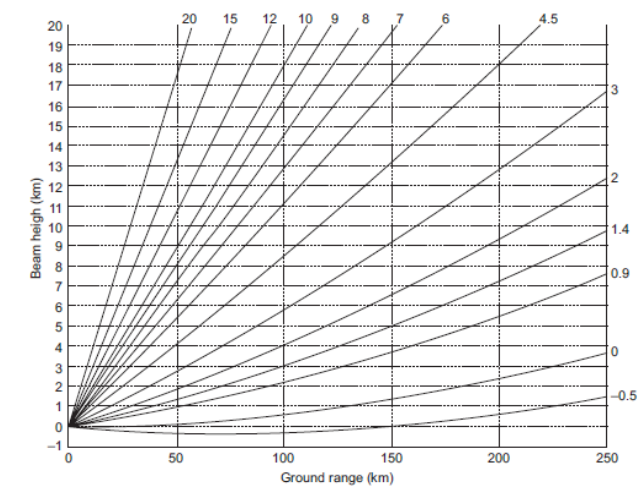

Gambar 2. Jelajah gelombang radar pada kondisi atmosfer standar (Novo \& Raga, 2013).

Berdasarkan Gambar 1 terlihat bahwa secara umum terdeteksinya nilai rain rate oleh MRR berada pada kisaran waktu yang sama dengan terdeteksinya nilai rain rate oleh radar cuaca WR-2100. Pada tanggal 28 Januari, kisaran nilai rain rate berada pada sekitar pukul 17.00-19.00 WIB. Pada tanggal 31 Januari, terdapat dua kisaran waktu terdeteksinya nilai rain rate, yaitu sekitar 12.00-13.30 WIB dan sekitar 16.45-18.15 WIB. Sementara itu, terdeteksinya nilai rain rate pada tanggal 2 Februari berada di kisaran waktu sekitar 15.0019.00 WIB, tanggal 8 Februari berada di kisaran waktu sekitar 11.00-17.30 WIB, dan tanggal 14 Februari berada di kisaran waktu sekitar 12.3019.00 WIB.

Akan tetapi, berdasarkan Gambar 1, secara umum juga terlihat bahwa radar cuaca WR-2100 mendeteksi rain rate dengan nilai yang tinggi hingga lapisan dengan ketinggian yang lebih tinggi daripada yang dideteksi oleh MRR. Pada Gambar 1 (a), terlihat bahwa pada sekitar pukul 17.30 WIB tanggal 28 Januari, radar cuaca WR-2100 mendeteksi rain rate dengan kisaran nilai $20-30 \mathrm{~mm} / \mathrm{jam}$ hingga ketinggian $7500 \mathrm{~m}$.
Sementara itu, lapisan tertinggi terdeteksinya nilai rain rate yang signifikan oleh MRR selama rentang waktu pengukuran maksimum hanya berada pada ketinggian $6250 \mathrm{~m}$. Masih pada tanggal yang sama, hal serupa juga jelas terlihat pada waktu sekitar 18.30 WIB yang mana radar cuaca WR-2100 mendeteksi nilai rain rate dengan kisaran 70-80 mm/jam hingga lapisan dengan ketinggian $4000 \mathrm{~m}$, sedangkan pada lapisan tersebut MRR hanya mendeteksi nilai rain rate sekitar $30 \mathrm{~mm} / \mathrm{jam}$.

Pada tanggal 31 Januari, pada kisaran waktu sekitar 17.00 WIB, radar cuaca WR-2100 mendeteksi nilai rain rate dengan kisaran paling rendah $10-15 \mathrm{~mm} / \mathrm{jam}$ di semua lapisan hingga ketinggian $7 \mathrm{~km}$. Semakin rendah dari lapisan ketinggian $7 \mathrm{~km}$, nilai rain rate yang terdeteksi tersebut pun semakin tinggi, hingga mencapai kisaran $45-50 \mathrm{~mm} / \mathrm{jam}$ mulai dari lapisan sekitar $3000 \mathrm{~m}$ ke bawah. Sementara itu, pada kisaran waktu yang sama berdasarkan MRR, nilai rain rate pada ketinggian lebih dari $3,5 \mathrm{~km}$ hanya berkisar kurang dari $5 \mathrm{~mm} / \mathrm{jam}$, bahkan kurang dari $1 \mathrm{~mm} / \mathrm{jam}$.

Pada tanggal 2 Februari, terlihat jelas bahwa radar WR-2100 mendeteksi rain rate dengan nilai mencapai kisaran 40-45 mm/jam hingga lapisan dengan ketinggian mencapai $5000 \mathrm{~m}$ pada kisaran waktu sekitar 17.00-17.45 WIB. Untuk lapisan dengan ketinggian lebih dari $5000 \mathrm{~m}$ pun nilai rain rate yang terdeteksi oleh radar cuaca WR-2100 masih tinggi pada kisaran waktu tersebut. Sementara itu berdasarkan MRR, terdeteksinya nilai rain rate pada kisaran waktu tersebut hanya berada hingga lapisan dengan ketinggian sekitar $3750 \mathrm{~m}$.

Pada tanggal 8 Februari, pada kisaran waktu sekitar 15.30-16.30 WIB, radar cuaca WR2100 mendeteksi nilai rainrate pada kisaran 25$30 \mathrm{~mm} / \mathrm{jam}$ pada ketinggian sekitar $5 \mathrm{~km}$ hingga $7 \mathrm{~km}$, sedangkan nilai rainrate pada kisaran waktu tersebut berdasarkan MRR hanya berkisar kurang dari $5 \mathrm{~mm} / \mathrm{jam}$, bahkan kurang dari 1 $\mathrm{mm} / \mathrm{jam}$ pada ketinggian lebih dari $5,5 \mathrm{~km}$.

Pada tanggal 14 Februari, pada kisaran waktu sekitar 12.30-13.30 WIB, radar cuaca WR2100 mendeteksi nilai rainrate pada kisaran 35$50 \mathrm{~mm} / \mathrm{jam}$ pada ketinggian sekitar $5 \mathrm{~km}$ hingga $7 \mathrm{~km}$. Sementara itu, pada kisaran waktu 12.3013.30 WIB berdasarkan MRR, nilai rainrate pada ketinggian lebih dari $3,5 \mathrm{~km}$ hanya berkisar kurang dari $5 \mathrm{~mm} / \mathrm{jam}$.

Namun, berdasarkan Gambar 1 juga telihat bahwa secara umum nilai-nilai rain rate yang ditunjukkan oleh MRR sedikit lebih besar dibandingkan dengan yang ditunjukkan oleh radar cuaca WR-2100. Lebih jelas, hal tersebut dapat terlihat pada Gambar 3. Gambar 3 memerlihatkan profil Rain Rate pukul 07.0019.00 WIB di lapisan $500 \mathrm{~m}$ tanggal 28 Januari (a), 31 Januari (b), 2 Februari (c), 8 Februari (d), dan 14 Februari 2016 (e), baik berdasarkan MRR (i), maupun berdasarkan radar WR-2100 (ii). 


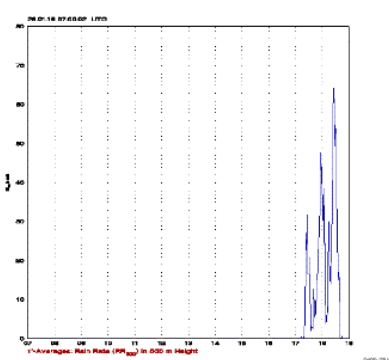

(a) $\mathrm{i}$

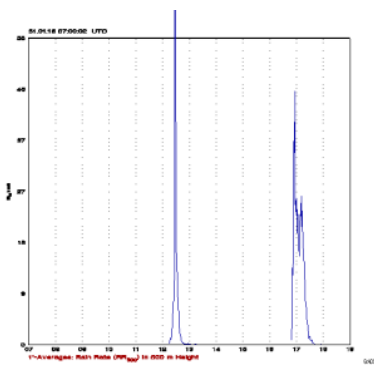

(b) $\mathrm{i}$

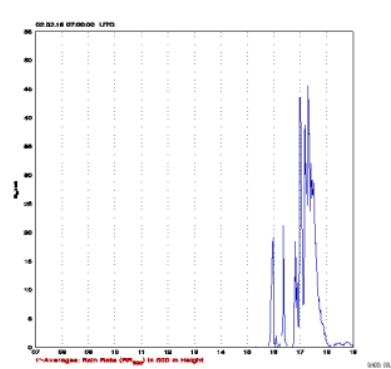

(c) $\mathrm{i}$

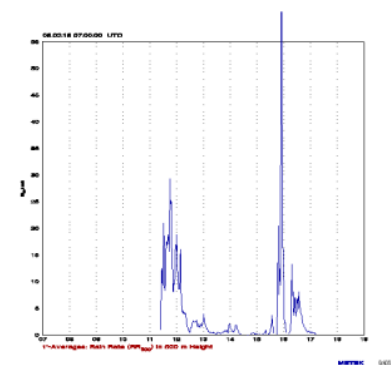

(d) $\mathrm{i}$

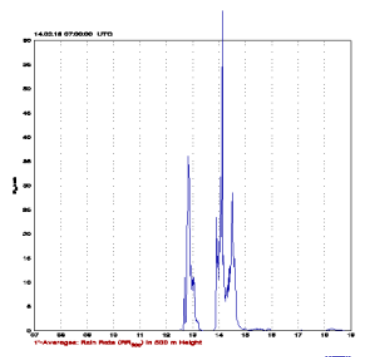

(e) i

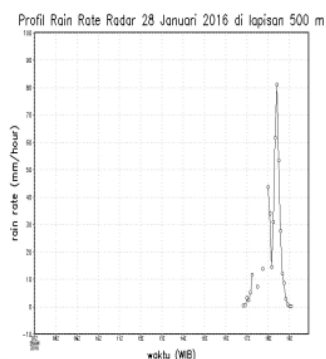

(a) ii

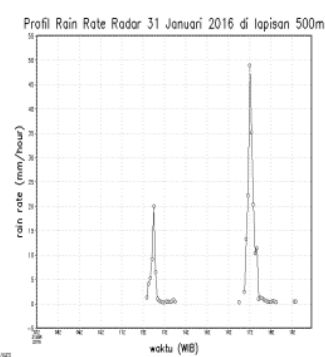

(b) ii

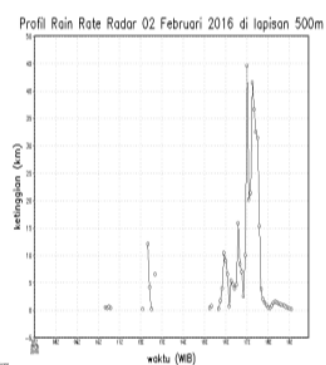

(c) ii

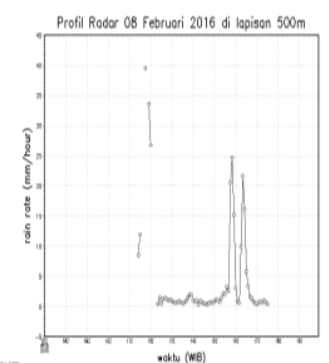

(d) ii

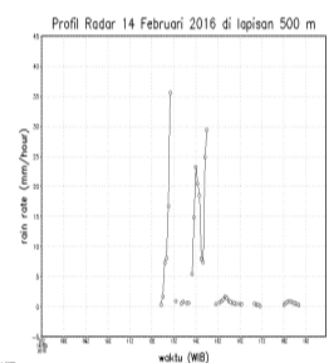

(e) ii
Gambar 3. Profil Rain Rate pukul 07.00-19.00 WIB di lapisan $500 \mathrm{~m}$ tanggal 28 Januari (a), 31 Januari (b), 2 Februari (c), 8 Februari (d), dan 14

Februari 2016 (e) berdasarkan MRR (i) dan berdasarkan radar WR-2100 (ii).

Berdasarkan Gambar 3, nilai rain rate yang terdeteksi oleh MRR di lapisan ketinggian $500 \mathrm{~m}$ secara umum cenderung sedikit lebih tinggi dibandingkan yang terdeteksi oleh radar cuaca WR-2100, namun berdasarkan Gambar 1 nilainilai rain rate di lapisan-lapisan yang lebih tinggi terdeteksi jauh lebih rendah oleh MRR dibandingkan oleh radar cuaca WR-2100. Pada Ketinggian lapisan tertinggi terdeteksinya nilai rain rate oleh MRR pun lebih rendah dibandingkan dengan ketinggian lapisan tertinggi terdeteksinya nilai rain rate oleh radar cuaca WR2100. Kedua hal tersebut diduga dikarenakan beberapa hal yang terkait dengan proses pengukuran kedua instrumen itu sendiri.

Seperti yang telah diketahui, MRR merupakan jenis radar yang melakukan pengukuran secara vertikal. Oleh karena itu, proses pengukuran lapisan-lapisan atas oleh MRR diduga akan lebih dipengaruhi atau terganggu oleh atenuasi yang terjadi oleh lapisan-lapisan di bawahnya, sedangkan dalam proses pembuatan profil vertikal hujan oleh radar cuaca WR-2100, gelombang elektromagnetik tidak ditransmisikan langsung secara vertikal di titik lokasi yang ingin diamati profilnya, melainkan dari sisi samping lokasi tersebut mulai dari titik terendah hingga ke titik tertinggi sesuai dengan sudut elevasi dalam pengoperasian radar WR2100 tersebut.

Atenuasi yang mungkin terjadi pada radar cuaca WR-2100 adalah atenuasi di lokasi berbeda yang dilalui selama gelombang tersebut dalam perjalanan menuju lokasi yang diamati. Dengan demikian, hasil pengukuran suatu titik lokasi tertentu pada ketinggian oleh radar cuaca WR-2100 tidak saling mempengaruhi dengan ketinggian di atasnya maupun di bawahnya.

Atenuasi adalah proses pelemahan radiasi elektromagnetik dikarenakan material beserta kerapatannya yang terdapat di suatu medium yang dilalui radiasi elektromagnetik tersebut. Di atmosfer, oksigen dan uap air merupakan penyebab atenuasi yang paling signifikan, dibandingkan nitrogen dan banyak gas lainnya (Rinehart, 2010).

Gelombang dengan frekuensi atau panjang gelombang tertentu mengalami atenuasi yang berbeda intensitasnya dengan yang dialami oleh gelombang dengan frekuensi atau panjang gelombang lainnya. MRR dan radar cuaca WR2100 memancarkan gelombang dengan frekuensi yang berbeda. MRR termasuk jenis radar K-Band (18-27 GHz) yang beroperasi pada frekuensi $24.1 \mathrm{GHz}$, sedangkan radar cuaca WR2100 termasuk jenis radar X-Band $(8-12 \mathrm{GHz})$ yang beroperasi pada frekuensi $9.1 \mathrm{GHz}$.

Berdasarkan Gambar 4, terlihat bahwa atenuasi oleh uap air semakin meningkat seiring meningkatnya frekuesi gelombang, hingga mencapai puncak pada frekuensi sekitar $20 \mathrm{GHz}$ sebelum akhirnya turun kembali seiring bertambahnya frekuensi (Bean \& Dutton, 1961). 


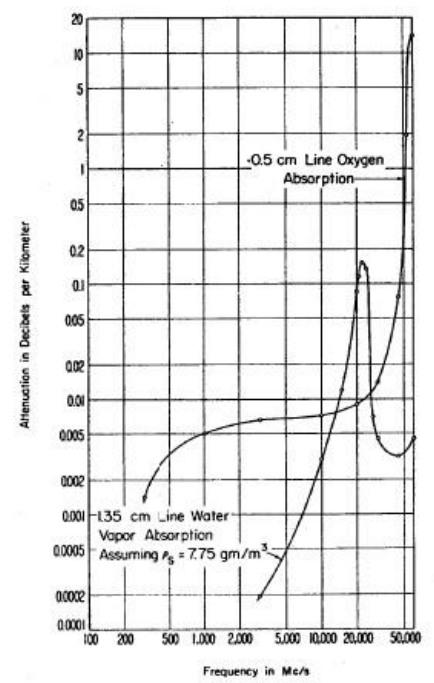

Gambar 4. Atenuasi atmosfer oleh uap air dan oksigen pada tekanan standar (1013.25 mb) sebagai fungsi frekuensi (Bean \& Dutton, 1961).

Dengan demikian, atenuasi oleh uap air terhadap gelombang yang dipancarkan oleh MRR lebih besar dibandingkan terhadap gelombang yang dipancarkan oleh radar WR2100, namun besarnya tidak terlalu signifikan sehingga tidak terlalu memengaruhi hasil pengukuran. Hal ini terlihat dari nilai rain rate yang tidak terlalu berbeda jauh antara yang dihasilkan MRR dengan yang dihasilkan oleh radar cuaca WR-2100 pada lapisan bawah, seperti pada Gambar 2 sebelumnya.

Gambar 5 (a)-(e) berikut memperlihatkan profil rain rate dengan cakupan area oleh radar WR-2100 pada beberapa waktu yang mana nilai rain rate nya tinggi untuk daerah Dramaga, Bogor pada lapisan-lapisan atas. Tanda panah pada masing-masing gambar menghubungkan lokasi radar radar cuaca WR-2100 (Koordinat: $6.3509323^{\circ}, \quad 106.6592642^{\circ}$ ) dengan lokasi pantauan Dramaga, Bogor (koordinat: $-6.55253^{\circ}$, $106.745^{\circ}$ ). Gambar 5 tersebut sebagai gambaran umum mengenai kondisi jalur yang dilewati gelombang radar cuaca WR-2100 dari keberadaannya hingga ke lokasi pantauan.

Berdasarkan Gambar 5, terlihat bahwa pada kejadian-kejadian terdeteksinya nilai rain rate yang tinggi di Dramaga, Bogor, ada saat yang mana kondisi jalur yang dilewati gelombang pada saat yang bersamaan cerah (tidak ada nilai rain rate terdeteksi), namun ada juga yang sebaliknya, yaitu gelombang radar melewati daerah yang sedang hujan deras sebelum sampai ke lokasi pantauan Dramaga, Bogor. Akan tetapi, nilai rain rate yang terdeteksi di Dramaga, Bogor tetap tinggi. Gelombang radar cuaca WR-2100 sebenarnya tidak bergerak dengan ketinggian yang konstan dari sumber radar, melainkan bergerak dengan sudut elevasi tertentu. Akan tetapi, secara umum Gambar 5 dapat memperlihatkan kondisi daerah yang dilalui gelombang radar dari sumbernya hingga ke lokasi pantauan Dramaga, Bogor.

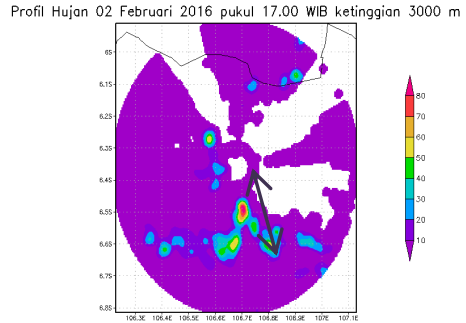

(a)

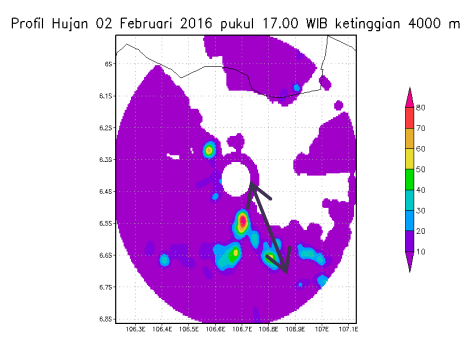

(b)

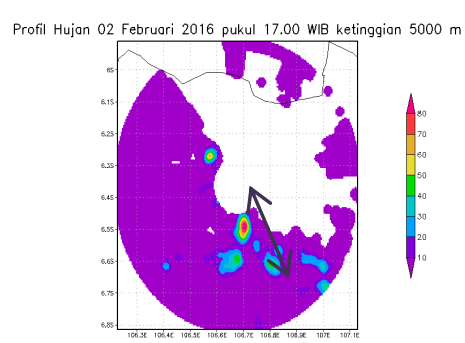

(c)

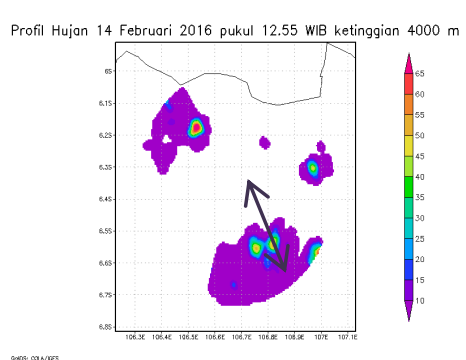

(d)

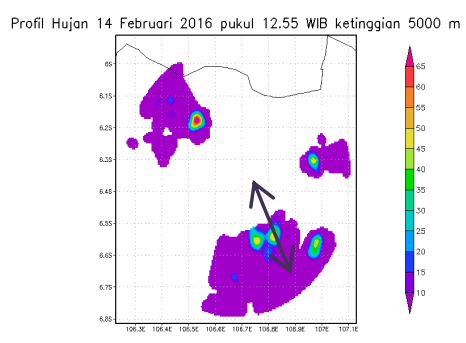

(e)

Gambar 5. Profil rain rate berdasarkan radar cuaca WR-2100 pada tanggal 02 Februari 2016 pukul 17.00 WIB di ketinggian $3000 \mathrm{~m}$ (a), tanggal 02 Februari 2016 pukul 17.00 WIB di ketinggian $4000 \mathrm{~m}$ (b), tanggal 02 Februari 2016 pukul 17.00 WIB di ketinggian $5000 \mathrm{~m}$ (c), tanggal 14 Februari 2016 pukul 12.55 WIB di ketinggian $4000 \mathrm{~m}$ (d), dan tanggal 14 Februari 2016 pukul 12.55 WIB di ketinggian $5000 \mathrm{~m}$ (e). 
Selain berbeda dalam hal frekuensi gelombang yang digunakan, dalam penentuan nilai rain rate, MRR dan radar cuaca WR-2100 juga berbeda dalam hal persamaan dasar yang digunakan. Pada radar cuaca WR-2100, dasar perhitungannya adalah persamaan yang umum digunakan oleh banyak radar cuaca, yang langsung menghubungkan reflektivitas radar, $z$, dengan rain rate, $R$, dengan bentuk umum sebagai berikut:

$$
z=a R^{b}
$$

$a$ dan $b$ pada persamaan di atas adalah konstanta yang nilainya dapat berbeda-beda, tergantung lokasi geografis dan musim (kondisi iklim), fase presipitasi (komposisi air, es, dan salju yang berbeda) dan intensitas (jenis storm dan distribusi ukuran butir), serta variabilitas dalam storm yang sama dan dari storm ke storm (Cyr, 2014). Salah satu persamaan hubungan z$\mathrm{R}$ yang banyak digunakan adalah persamaan Marshall-Palmer, $z_{\mathrm{e}}=200 \mathrm{R}^{1,6}$ yang digunakan untuk ukuran-ukuran butir dari 1 hingga $3 \mathrm{~mm}$. Gambar 6 berikut memerlihatkan perbandingan beberapa persamaan hubungan $z-R$, yaitu Marshall-Palmer, GATE $\left(\mathrm{z}=230 R^{1.25}\right)$, Swiss Meteorological Agency default $\left(z=315 R^{1.5}\right)$, dan US National Weather Service default $\left(z=300 R^{1.4}\right)$ (Yuter, 2015).

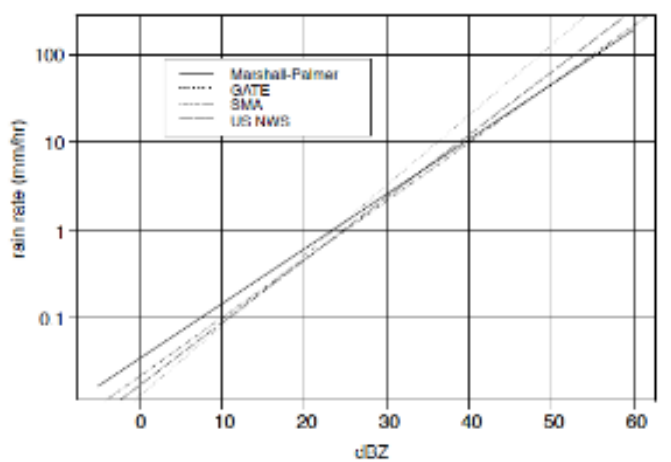

Gambar 6. Grafik beberapa persamaan hubungan z-R (Yuter, 2015)

Sementara itu, nilai rain rate MRR bersumber dari nilai pergeseran Doppler yang diturunkan menjadi kecepatan jatuh butir air (falling velocity, v), yang kemudian juga diturunkan lagi menjadi distribusi ukuran butir air (drop size distribution, D), dan kemudian barulah diturunkan kembali menjadi nilai rain rate, dengan persamaan berikut:

$$
R=\frac{\pi}{6} \int_{D \min }^{D \operatorname{maz}} N(D) v(D) D^{3} d D
$$

Jadi, berbeda dengan radar cuaca yang melakukan asumsi awal terhadap disribusi ukuran butir air (DSD) sebelum mengestimasi intensitas presipitasi, sebaliknya MRR melakukan pengukuran terhadap DSD sebelum dapat menentukan intensitas hujan (rain rate, R) (Maahn and Kollias, 2012).

Persamaan dalam penentuan kecepatan jatuh yang merupakan nilai yang paling berkotribusi besar dalam penentuan nilai rain rate pada MRR, adalah sebagai berikut:

$$
v_{d}(z)=\int_{v_{\min }}^{v_{\max }} \eta(v, z) v d v
$$

Hal lain yang juga mungkin memengaruhi perbedaan nilai rain rate yang dideteksi oleh MRR dengan yang dideteksi oleh radar cuaca adalah perbedaan scanned volume oleh gelombang MRR dan gelombang radar cuaca WR-2100 saat sampai di titik lokasi pantauan.

\section{KESIMPULAN}

Terdeteksinya nilai rain rate oleh MRR dan oleh radar cuaca WR-2100 berada pada kisaran waktu yang sama.

Secara umum nilai tertinggi rain rate di lapisan-lapisan bawah sedikit lebih besar oleh MRR daripada oleh radar cuaca WR-2100, akan tetapi pada lapisan-lapisan yang lebih tinggi pada saat kejadian hujan sedang, radar mendeteksi nilai-nilai RR yang jauh lebih tinggi daripada yang terdeteksi oleh MRR.

Lapisan tertinggi terdeteksinya nilai rain rate yang besar oleh MRR berada pada ketinggian yang jauh lebih rendah dibandingkan dengan lapisan tertinggi terdeteksinya nilai rain rate yang besar oleh radar WR-2100.

Lebih rendahnya nilai rain rate yang dihasilkan di lapisan-lapisan atas atau lebih rendahnya ketinggian maksimum terdeteksinya nilai rain rate oleh MRR pada saat kejadian hujan dibandingkan dengan yang dihasilkan oleh radar cuaca WR-2100 diduga dikarenakan proses pengukuran rain rate yang secara vertikal sehingga pengukuran di suatu lapisan ketiggian tertentu dipengaruhi oleh atenuasi yang terjadi di lapisan-lapisan bawahnya.

\section{DAFTAR PUSTAKA}

Bean, B.R., Dutton, E.J. (1961). Concerning Radiosondes, Lag Constants, and Radio Refractive Index Profiles. Journal Of Geophysical Research, 66(11), 3717-3722. doi: 10.1029/Jz066i011p03717

Berne, A., Uijlenhoet, R. (2006). Quantitative Analysis of X-Band Weather Radar Attenuation Correction Accuracy. Natural Hazards and Earth System Sciences, 6, 419-425. doi: 10.5194/nhess-6-419-2006

Chakravarty, K., Kamble, S., Das, S., Kalapureddy, M.C.R., Deshpande, S., Das, S. (2014). Characteristics of Orographic Precipitation by Using Doppler Radar And Disdrometer. IEEE. doi: 10.13140/2.1.4711.8727 
Cyr, I. (2014). Estimation of Z-R Relationship and Comparative Analysis of Precipitation Data from Colocated Rain-Gauge, Vertical Radar and Disdrometer. Thesis. Norwegia: Norwegian University of Science and Technology.

Kneifel, S., Maahn, M., Peters, G., Simmer, C. (2011). Observation of Snowfall with a Low-Power Fm-Cw K-Band Radar (Micro Rain Radar). Meteorology And Atmospheric Physics, 113(1), 75-87. doi: 10.1007/S00703-011-0142-Z

Maahn, M., Kollias, P. (2012). Improved Micro Rain Radar Snow Measurements Using Doppler Spectra Post-Processing. Atmospheric Measurement Techniques, 5, 2661-2673. doi: 10.5194/amt-5-2661-2012

Novo, S., Raga, G.B. (2013). The Properties of Convective Storms in Central Mexico: A Radar and Lightning Approach. Atmosfera, 26(4), 461-472. doi: 10.1016/S01876236(13)71088-9

Peter, G., Fischer, B., Andersson, T. (2002). Rain Observation with a Vertically Looking Micro Rain Radar (MRR). Boreal Environment Research, 7, 353-362.
Rinehart, R.E. (2010). Radar for Meteorologists $5^{\text {th }}$ Edition. Nevada Missouri: Rinehart Publications.

Saavedra, P., Battaglia, A., Simmer, C. (2012). Partitioning of Cloud Water and Rainwater Content by Ground-Based Observations with the Advanced Microwave Radiometer for Rain Identification (ADMIRARI) in Synergy with a Micro Rain Radar. Journal of Geophysical Research, 117, 1-18. doi: 10.1029/2011jd016579

Smith, B.L., Blaes, J.L. (2015). Examination of a Winter Storm Using a Micro Rain Radar and AMDAR Aircraft Soundings. NWA Journal of Operational Meteorology, 3(14). 156-171. doi: 10.15191/Nwajom.2015.0314

Yang, H.Y., Chang, K.H., Kang, S.T. (2013). Combined Microwave Radiometer and Micro Rain Radar for Analysis of Cloud Liquid Water. Journal of The Chosun Natural Science, 6(1), 12-15. doi: 10.13160/ricns.2013.6.1.012

Yuter, S.E. (2015). Precipitation Radar. Washington: University of Wasington. 